\title{
Rumen microbial ecology in reindeer - adaptations to a unique diet*
}

\author{
M.A. Sundset ${ }^{1,2}$, I.K.O. Cann ${ }^{2}$, S.D. Mathiesen ${ }^{3}$ and R.I. Mackie ${ }^{2}$ \\ ${ }^{1}$ Department of Arctic Biology and Institute of Medical Biology, University of Tromsø \\ 9037 Tromsø, Norway \\ ${ }^{2}$ Department of Animal Sciences, University of Illinois at Urbana-Champaign, IL, USA \\ ${ }^{3}$ Section of Arctic Veterinary Medicine, The Norwegian School of Veterinary Science \\ 9292 Tromsø, Norway
}

\begin{abstract}
Svalbard reindeer are isolated on the high-arctic archipelago of Svalbard under austere nutritional conditions, while the semi-domesticated Norwegian reindeer migrate between lush coastal summer pastures and inland taiga and boreal forest habitats with ground lichens in winter on mainland Norway. We propose that interactions between reindeer and Arctic plants through 15 million years of evolution have resulted in a unique rumen microbial ecosystem, and present data on rumen bacterial diversity analysed by PCR amplification and sequencing of $16 \mathrm{~S}$ rDNA clone libraries from these sub-species of reindeer. Resulting sequences represent novel bacteria different from those reported in other ruminants.
\end{abstract}

KEY WORDS: plant-herbivore interactions, reindeer, rumen, bacteria, 16S rDNA clone libraries

\section{INTRODUCTION}

The Svalbard reindeer (Rangifer tarandus platyrhynchus) lives under extremely austere nutritional conditions at the arctic archipelago of Svalbard $\left(74-81^{\circ} \mathrm{N}\right)$, where snow and ice cover the vegetation for more than eight months of the year. They have never been domesticated, are non-migratory and forage on tundra vegetation which is locally lush with herbs, dwarf shrubs, grasses and sedges in summer, while a polar desert vegetation of mosses and poor quality vascular plants dominate the winter diet (Sørmo, 1998). Norwegian reindeer

\footnotetext{
* Supported by the Reindeer Husbandry Research Fund, the University of Tromsø, the Norwegian Research Council, The Roald Amundsen Centre for Arctic Research, University of Troms $\varnothing$, and the Centre for Sámi Studies, University of Tromsø (all national)

${ }^{1}$ Corresponding author: e-mail: monicas@fagmed.uit.no
} 
(R. t. tarandus) on mainland Norway are herded by the Saami and migrate seasonally up to $350 \mathrm{~km}$ between lush coastal summer pastures and inland taiga and boreal forest habitats in winter, including a significant proportion of ground lichens (Cladonia spp.) in their diet (Storeheier et al., 2002a,b). Seasonal variations in viable numbers of rumen bacteria as well as the composition of the viable population are found in both sub-species (Orpin et al., 1985; Olsen et al., 1997). The purpose of this project was to gain a better understanding of the natural rumen microbial ecology and hence the digestive adaptations in these Arctic ruminants, using new molecular techniques based on sequence heterogeneity of the 16S rDNA. Furthermore, the effect of rumen manipulations through artificial feeding of semi-domesticated Norwegian reindeer, on the rumen bacterial diversity was also studied.

\section{MATERIAL AND METHODS}

\section{Animals and diet}

Rumen samples for molecular ecological analysis were obtained July 2001 from three male Norwegian reindeer calves on natural summer pastures on the coast of northern Norway and five male Norwegian reindeer fed a commercially available pelleted concentrate diet for reindeer (RF-80 with a chemical composition of, $\%$ : crude protein 10.3 , water soluble carbohydrates 8.2 , cellulose 15.9 , and hemicellulose 27.9) (Storeheier et al., 2002b, 2003). Likewise, five adult female Svalbard reindeer were slaughtered and sampled October 2001 in Colesdalen, Svalbard on natural late summer pasture.

\section{DNA fingerprinting of bacterial populations}

Total genomic DNA from whole rumen contents was extracted using a UltraClean Soil DNA Kit (MoBio Laboratories Inc.) followed by Proteinase $\mathrm{K}$ treatment. The bacterial $16 \mathrm{~S}$ rRNA genes were amplified using primers $27 \mathrm{f}$ (5'AGAGTTTGATCMTGGCTCAG 3') and 1525r (5'AAGGAGGTGWTCCAR CC 3').

\section{Cloning and sequencing}

16S rDNA amplicons from each group of animals were cloned using a pGEM-T vector system (Promega) and transformation was done by heat- and electro-shock resulting in 300-1000 colonies/plate (LB medium with X-gal, IPTG and Ampicillin). Transformants were picked at random and clones cultured in 3-6 $\mathrm{ml}$ of LB amp $(50 \mathrm{mg} / \mathrm{ml})$ over night. Recombinant plasmids were extracted using a QIA prep Spin Miniprep Kit, and tested for insert $(\sim 1.5 \mathrm{~Kb})$ on a $1 \%$ agarose gel. Enzymatic digest with SauA3 I was performed to check for diversity among the recombinants. DNA sequence analysis of the 16S rDNA 
insert was carried out using the primers M13 FW-21, M13 RW-48 and 338Bact (5' ACTCCTACGGGAGGCAGC 3') with a 337 DNA Sequencer (Applied Biosystems).

\section{Sequence analysis}

Assemblage of sequences was done using SeqMan ${ }^{\mathrm{TM}}$ II v.5.05 (DNASTAR Inc.). The sequences were aligned using CLUSTAL X v. 1.83 and phylogenetic analysis was performed using the neighbor-joining method. Statistical significance of branching was verified by bootstrapping involving construction and analysis of 1000 trees from the data set. Reference sequences (previously cultured and characterized rumen bacteria) were obtained from the GenBank Database.

\section{RESULTS}

A total of $12016 \mathrm{~S}$ rDNA sequences $(1.5 \mathrm{~kb})$ were analysed from the three libraries prepared from whole rumen contents from Norwegian reindeer (on natural summer pasture and fed RF-80) and Svalbard reindeer (on natural late summer pasture). In the first library (Norwegian reindeer on natural summer pasture) of 34 clones, $67.6 \%$ of the sequences belonged to the low $\mathrm{G}+\mathrm{C}$ Gram-positive bacteria phylum and $32.4 \%$ to the Cytophaga-Flavobacter-Bacteroides bacteria. In the second library (Norwegian reindeer fed concentrate diet) of 56 clones, as much as $91.1 \%$ of the clones belonged to the low $\mathrm{G}+\mathrm{C}$ Gram-positive bacteria phylum and only $7.1 \%$ to the Cytophaga-Flavobacter-Bacteroides bacteria. One of the clones belonged to the Proteobacteria. And in the third library (Svalbard reindeer on natural pasture) of 30 clones, $56.7 \%$ of the sequences belonged to the low $\mathrm{G}+\mathrm{C}$ Gram-positive bacteria phylum and $43.3 \%$ to the Cytophaga-FlavobacterBacteroides bacteria. Bacterial 16S rDNA sequences differed between the three groups of animals.

\section{DISCUSSION AND CONCLUSIONS}

Mechanistic knowledge of the rumen microbial ecosystem is crucial in order to manipulate the efficiency of ruminant digestion, but may also be of importance to measure future impacts of human intervention and environmental changes. We propose that adapting to a heterogenous diet of arctic plants including lichens through 15 million years of evolution (Randi et al., 1998) has resulted in a unique rumen microbial ecosystem in reindeer. In support of our hypothesis, a recent study by Mackie et al. (2003) on the ecology of the uncultivated bacterium Oscillospira showed that the diversity of Oscillospira was greater in reindeer compared to other ruminants examined (sheep and cattle). Interestingly, some of the Oscillospira phylotypes were also common to all of these geographically 
distant ruminants. Supplementary feeding of reindeer during winter has increased in the Saami reindeer husbandry in Norway during the past 10-15 years, a factor that may influence the natural gastrointestinal microbiota of these animals. This is illustrated by the increase in proportion of clones representing the low $\mathrm{G}+\mathrm{C}$ gram positive bacteria in artificially fed (91.1\%) compared with naturally fed (67.6\%) Norwegian reindeer. The composition of the rumen bacterial population also varied between the two sub-species of reindeer studied, possibly due to dietary differences. The $16 \mathrm{~S}$ rDNA sequences analysed in this study represented novel rumen bacteria not yet isolated or characterised. Their functional role, however, remains unknown because of our inability to cultivate them under laboratory conditions in order to establish their metabolic properties.

\section{REFERENCES}

Mackie R.I., Aminov R.I., Hu W., Klieve A.V., Ouwerkerk D., Sundset M.A., Kamagata Y., 2003. Ecology of uncultivated Oscillospira species in the rumen of cattle, sheep and reindeer as assessed by microscopy and molecular approaches. Appl. Environ. Microbiol. 69, 6808-6815

Olsen M.A., Aagnes T.H., Mathiesen S.D., 1997. The effect of timothy silage on the bacterial population in rumen fluid of reindeer (Rangifer tarandus tarandus) from natural summer and winter pasture. FEMS Microbiol. Ecol. 24, 127-136

Orpin C.G., Mathiesen S.D., Greenwood Y., Blix A.S., 1985. Seasonal changes in the ruminal microflora of the high-arctic Svalbard reindeer (Rangifer tarandus platyrhynchus). Appl. Environ. Microbiol. 30, 144-151

Randi E., Mucci N., Pierpaoli M., Douzery E., 1998. New phylogenetic perspectives on the Cervidae (Artiodactyla) are provided by the mitochondrial cytochrome b gene. Proc. Roy. Soc. London, Ser. B 265, 793-801

Sørmo W., 1998. Interactions between the function of the digestive system and the pasture plants in reindeer. $\mathrm{PhD}$. Thesis, University of Tromsø (Norway)

Storeheier P.V., Mathiesen S.D., Tyler N.J.C., Olsen M.A., 2002a. Nutritive value of terricolous lichens for reindeer in winter. Lichenologist 34, 247-257

Storeheier P.V., Mathiesen S.D., Tyler N.J.C., Schelderup I., Olsen M.A., 2002b. Utilisation of nitrogen and mineral-rich vascular plants by reindeer in winter. J. Agr. Sci. 139, 151-160

Storeheier P.V., Sehested J., Diernæs L., Sundset M.A., Mathiesen S.D., 2003. Effects of seasonal changes of food quality and food intake on the transport of sodium and butyrate across ruminal epithelium of reindeer. J. Comp. Physiol. 173, 391-399 